\title{
Enhancing corrosion resistance of RC pipes using geopolymer mixes when subjected to aggressive environment
}

\author{
Lamiaa M. Omer ${ }^{1 *}$, Mohamed S. Gomaa ${ }^{2}$, Waleed H. Sufe ${ }^{3}$, Alaa A. Elsayed ${ }^{2}$ and Hany A. Elghazaly ${ }^{2}$
}

\author{
* Correspondence: Imo00@fayoum. \\ edu.eg \\ ${ }^{1}$ Faculty of Engineering, Fayoum \\ University, Faiyum, Egypt \\ Full list of author information is \\ available at the end of the article
}

\begin{abstract}
The durability of reinforced concrete (RC) pipes depends upon the corrosion resistance of the reinforcing steel and the resistance of concrete mixes against an aggressive environment. This research paper aims to compare the performance of R.C. pipes made of ordinary Portland cement (OPC) concrete mixtures with others made of two different geopolymer concrete mixes based on different ratios of granulated blast furnace slag (GBFS), fly ash (FA), and pulverized red brick (RB) subjected to three different environments, ambient, tap water (TW), and an aggressive environment, and a solution of $10 \%$ magnesium sulfates $+5 \%$ chloride (MS-CL). An accelerated corrosion setup has been applied to accelerate the corrosion process in the tested samples. The evaluation of change of compressive strength of concrete and microstructure of different mixes was investigated too. Fourier transform infrared (FTIR) spectroscopy has been studied on all pipes. Geopolymer concrete mixes based on 90\% GBFS and 10\% RB show better results in all cases. Geopolymer concrete mixes based on 63\% GBFS, 27\% FA, and 10\% RB increase the concrete compressive strength in the magnesium sulfate and chloride environment by $5 \%$ compared to tap water. It can be concluded that the geopolymer concrete mixes produced of 90\% GBFS and 10\% RB perform well under all environments, and its microstructure shows stable behavior in an aggressive environment.
\end{abstract}

Keywords: Geopolymer, Pipes, Concrete, Corrosion, Compressive strength

\section{Introduction}

Water and sewer water pipes are usually exposed to highly aggressive media attacks. Therefore, there is an increasing need for new construction materials distinguished by high durability under aggressive media attacks rather than ordinary Portland cement. The most common disadvantages of ordinary Portland cement are environmental pollution from gas emission during the cement industry, deterioration under aggressive media attacks, and high cost. Geopolymer binder can be used in waste-water and water pipes more than phase like in concrete as a construction material or in mortar as a rehabilitation material in waste-water and water pipes [1, 2]. Geopolymers, classified as

(c) The Author(s). 2021 Open Access This article is licensed under a Creative Commons Attribution 4.0 International License, which permits use, sharing, adaptation, distribution and reproduction in any medium or format, as long as you give appropriate credit to the original author(s) and the source, provide a link to the Creative Commons licence, and indicate if changes were made. The images or other third party material in this article are included in the article's Creative Commons licence, unless indicated otherwise in a credit line to the material. If material is not included in the article's Creative Commons licence and your intended use is not permitted by statutory regulation or exceeds the permitted use, you will need to obtain permission directly from the copyright holder. To view a copy of this licence, visit http://creativecommons.org/licenses/by/4.0/. The Creative Commons Public Domain Dedication waiver (http://creativecommons.org/publicdomain/zero/1.0/) applies to the data made available in this article, unless otherwise stated in a credit line to the data. 
inorganic aluminosilicate polymers, are characterized by their high performance and low unit volume weight. Geopolymer composites have recently found wide use in many applications of constructions in addition to in repairing and strengthening buildings because of their high strength, environmental friendliness, and significant cost advantages [3-5].

$\mathrm{RC}$ pipes are widely used in infrastructure as they are characterized by their reliable long-term performance. The pipe may contain up to three welded reinforcement cages so as to withstand anticipated loads. The amount of welded reinforcement cages depends on multiple parameters (e.g., pipe diameter, pipe wall thickness, required strength, etc.) [6]. Using double spiral stirrups in the concrete of drainage pipes provides uniform constraint function and upgrades the resistance to deformation ability of drainage pipe [7]. During the loading process, pipes develop vertical and horizontal cracks on interior surfaces (crown and invert) and mid-height on exterior surfaces (spring lines), respectively. The locations of the crown, invert, and spring lines are shown in Fig. 1. To improve the service life of pipes in an aggressive sewer environment and limit their maintenance requirements, the cover thickness of pipes must be increased. So, using one layer of steel reinforcement in pipe design is better than using two layers to provide more concrete cover for the reinforcing steel [8].

The mechanism of corrosion of reinforcing steel in concrete is defined as an electrochemical process. The surface of the corroding steelworks is a composite of the anode and the cathode electrically connected through a body of steel itself. The factors which affect the corrosion of steel in concrete structures are aggregate size and its grading, the thickness of concrete cover over reinforcing steel, impurities in mixing and curing water, contaminants in aggregate, chloride ions that reach the rebar level either through the concrete ingredients or from the external environment, carbonation and entry of acidic gaseous pollutants to rebar, temperature and relative humidity, cement composition, presenting of oxygen, and moisture at the rebar level $[9,10]$. Several studies focused on the corrosion process by accelerated corrosion setup in different RC element applications [11-17]. The effect of a bond impairment is more effective than the decrease in the cross-sectional area of bars on the loss of tension force capacity [13]. During the pull-out test on corroded bars, an increase in the load-carrying capacity of slabs with a small amount of corrosion was recorded. A steady loading carrying capacity at $1 \%$ diameter loss was recorded, and then a decrease in loading carrying capacity at $2 \%$ diameter loss started.

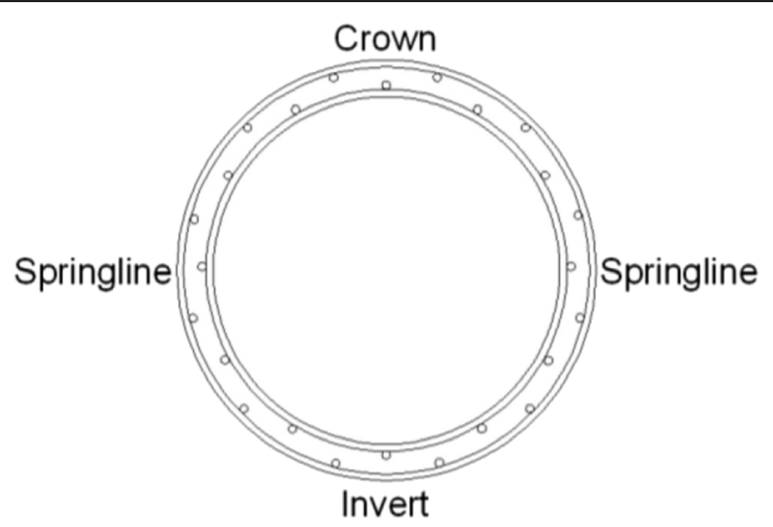

Fig. 1 Location of the crown, invert, and spring lines [3] 
The production of geopolymer concrete is by reacting an alkaline liquid with a source material rich in silica and alumina such as slag, fly ash, red mud, and silica fume. Geopolymer binder is used in many phases as an example; paste, mortar, and concrete in many investigations [18-22]. The most crucial feature of geopolymer concrete as new material is its high resistance to aggressive media attacks. Geopolymer mortar was used as a spray which forms a crystalline structural solution for increased resistance to acids and surface durability. It is characterized by fast curing, which allows the pipe to be rehabilitated quickly. In addition to fast curing, it is characterized by environmental effects resistance such as heat and cold [18]. By applying splitting, shear, significant cracking, and conical type failure tests on geopolymer mortar specimens, the geopolymer mortar specimens can be classified as brittle material [19]. Comparing geopolymer concrete to ordinary cement concrete in the case of precast units, geopolymer concrete is more environmentally friendly and economical than ordinary cement concrete [20].

Furthermore, geopolymer concrete has better workability than ordinary cement concrete of the same grade [21]. The amount of water and binder required in geopolymer concrete is less than regular cement concrete of the same grade workability level and the same compressive strength at 28 days [21]. After exposure to sulfate attack such as magnesium sulfate, the P.H. value of the solution, which contain geopolymer specimens, increase slightly during the first 14 days and after that has not changed [22-25].

The objective of the present research is to conduct an experimental study to investigate the different mixes of geopolymer mortar and concrete to achieve the optimum concrete mix for pipes. The effect of aggressive media (magnesium sulfate and chloride) and accelerated corrosion periods on the corrosion rate and infrared analysis (FTIR) of RC pipes were studied. This research sheds light on replacement OPC binder by geopolymer binder in different cases such as mortar and concrete. The comparison between the compressive strength of geopolymer and OPC mortar and concrete was recorded. The corrosion behavior of the reinforcing steel embedded in pipes is evaluated by using the Voltalab test. The microstructure of concrete was observed by scanning infrared analysis (FTIR). The paper also introduces the experimental program details containing the preparation of samples, casting of concrete, and curing technique. The details of the accelerated corrosion setup technique are presented; then, the results obtained from the performed experimental program are presented and discussed. The novelty of this research is that it shed light on the advantage of using geopolymer mixes in RC pipes, such as high strength performance, corrosion resistance, low cost, and environment-friendliness compared with OPC mix in RC pipes. Many researchers have also investigated the behavior of geopolymer material in an aggressive environment. However, it is infrequent to present the effect of geopolymer mixes in RC pipes after a long time of exposure to an aggressive environment by applying accelerated corrosion set up for three months on pipes. In addition, this study includes more than one aspect, such as geopolymer, engineering, chemistry, and material science.

\section{Experimental program}

\section{Concrete constituent materials' properties}

GGBFS, FA, RB, and OPC are used as base materials. X-ray fluorescence (XRF) analysis was utilized to determine their oxide composition (see Table 1). GGBFS is a side 
Table 1 Oxide composition (wt\%) of the raw materials, X-ray fluorescence (XRF) analysis of F.A., GGBFS, R.B., and OPC

\begin{tabular}{llllll}
\hline Items & & FA & GGBFS & RB & OPC \\
\hline Chemical composition in \% & $\mathrm{SiO}_{2}$ & 56.2 & 36.59 & 73.05 & 18.5 \\
& $\mathrm{Al}_{2} \mathrm{O}_{3}$ & 25.8 & 10.01 & 13.41 & 5.24 \\
$\mathrm{Fe}_{2} \mathrm{O}_{3}$ & 6.8 & 1.48 & 6.35 & 5.9 \\
$\mathrm{CaO}$ & 3.67 & 33.07 & 1.35 & 60.9 \\
$\mathrm{MgO}$ & 1.76 & 6.43 & 1.46 & 1.1 \\
& $\mathrm{SO}_{3}$ & 0.47 & 3.52 & 0.74 & 1.5 \\
$\mathrm{~K}_{2} \mathrm{O}$ & 0.01 & 0.74 & 0.91 & - \\
$\mathrm{Na}_{2} \mathrm{O}$ & 2.06 & 1.39 & 1.62 & - \\
& $\mathrm{Cl}$ & 0.52 & 0.05 & 0.18 & 0.002 \\
& L.O.L & 6 & 0 & 0.95 & 0.8 \\
\hline
\end{tabular}

product of rapid cooling of molten steel from Iron and Steel Factory-Helwan, Egypt, with a specific gravity of 3.52. FA is a product of coal's combustion supplied from a factory in Sadat City, Egypt, with a specific gravity of 1.9. RB was prepared by smashing fired clay bricks from Clay Brick Factories, Helwan Governate, Egypt, by a crusher to achieve a particle size less than $10 \mathrm{~mm}$ and with a specific density of 2.55 . Sodium hydroxide $(\mathrm{NaOH})$ is in the form of white flakes having a purity of $99 \%$, and the sodium silicate $\left(\mathrm{Na}_{2} \mathrm{SiO}_{3}\right)$ is in the form of white viscous liquid having a chemical composition of $\mathrm{Na}_{2} \mathrm{O}=8.9 \% \mathrm{SiO}_{2}=$ $28.7 \% \mathrm{H}_{2} \mathrm{O}=62.5 \%$ (by weight) with a specific gravity of 1.45 . The alkaline activator used was prepared from $\mathrm{Na}_{2} \mathrm{SiO}_{3}$ and $\mathrm{NaOH}$ at a constant of 3:1 by volume. Table 2 represents the mechanical properties of the used gravel and sand. The main physical and mechanical properties of the used ordinary Portland cement are listed in Table 3.

\section{Test variables}

In this study, three main mixes have been prepared in two phases; mortar and concrete. Tables 4 and 5 provide the mix id and the composition of the batch of mortar and concrete mixes, respectively. Six RC pipes with $500 \mathrm{~mm}$ effective length and an internal diameter of $500 \mathrm{~mm}$ reinforced by a single mild steel mesh of $8 \mathrm{~mm}$ diameter and $10 \varnothing 8 \mathrm{~mm}$ longitudinal reinforcement have been prepared. The pipes have been categorized, as shown in Table 6 .

\section{Reinforcing steel properties}

The used longitudinal and hoop reinforcements are mild steel plain bars of a nominal diameter of $8 \mathrm{~mm}$. Table 7 shows the geometrical and the mechanical properties for the used reinforcement. The reinforcement arrangement is shown in Figs. 2 and 3.

\section{Sample preparation}

The concrete mix has been designed to produce concrete with different compressive strengths for each of the three concrete mix types OPCA, GPCB, and GPCC. The casting of samples has been carried out in wooden form after placing the reinforcement inside the state. The concrete has been mixed in a rotating mixer of $100 \mathrm{l}$ capacity and compacted using an electrical poker vibrator. Figures. 4 and 5 show the stages of casting. The curing of the RC pipes has been carried out by putting the pipes in a laboratory field 
Table 2 Main physical and mechanical properties of the used gravel and sand

\begin{tabular}{lc}
\hline Gravel & \\
Unit weight & $1.56 \mathrm{t} / \mathrm{m}^{3}$ \\
Specific gravity & 2.85 \\
Crushing value & $13.76 \%$ \\
Sand & \\
Unit weight & $1.73 \mathrm{t} / \mathrm{m}^{3}$ \\
Specific gravity & 2.5 \\
\hline
\end{tabular}

in air curing as shown in Fig. 6 . Then, the specimens have been stored in the laboratory until applying the accelerated corrosion setup. During the casting of models, four standard $150 \mathrm{~mm}$ cubes have been taken, compacted by an electrical vibrator, and cured for a week, similar to the common curing period practice in the Egyptian construction industry. In addition, four mortar standard $50 \mathrm{~mm}$ cubes have been taken, compacted by an electrical vibrator, and cured in two cases; air and water are curing. The required samples for each mix have been prepared, and the reported results were the average of the four samples.

\section{Accelerated corrosion setup (ACS)}

An accelerated corrosion setup has been performed to precipitate the laboratory field's corrosion process to simulate the corrosion process in the actual field. Six concrete pipes have been filled with TW or MC-CL as mentioned in Table 6. Every pipe has been filled with water or aggressive media to work as an electrolyte. Stainless steel bars have been placed into the pipe and work as cathode, while the reinforcing steel bars in the pipes act as the anode. The current induced to accelerate corrosion has been applied to all pipes. The samples have been filled with solutions for one month before connecting the direct current (DC) power supply with variable resistance with a rate of $1 \mathrm{~mA} / \mathrm{cm}^{2}$. The setup has been applied for three months. Figures 7 and 8 show the accelerated corrosion setup.

\section{Method of investigation}

Compressive strength tests have been carried out on mortar samples after 7 and 28 days and on concrete samples after 7, 28, and flexural test days. Flexural tests have been applied by the loading frame on RC pipes [1]. The flexural test has been based on failure load, load-mid-span (vertical) deflection, and load-mid-span (horizontal) deflection. The loading frame used in the test program is 100.0 tons capacity and had a sufficiently large stroke of $300 \mathrm{~mm}$. During loading by the loading frame, strain measurements have been obtained by linear variable displacement transducer (LVDT) connected to the data acquisition system. Broken samples from applying the loading frame test on concrete

Table 3 Main physical and mechanical properties of the used ordinary Portland cement (CEM I) complying with ESS 4756-1/2013

\begin{tabular}{lll}
\hline Initial setting time & Hour & Minutes \\
Final setting time & 2 & 5 \\
& Hour & Minutes \\
Compressive strength at 3 days & 3 & 10 \\
Compressive strength at 7 days & $20 \mathrm{~N} / \mathrm{mm}^{2}$ & \\
\hline
\end{tabular}


Table 4 Mix id and mix batch composition of mortar mixes

\begin{tabular}{|c|c|c|c|c|c|c|c|}
\hline \multicolumn{2}{|l|}{ Mortar indent } & \multirow{2}{*}{$\begin{array}{l}\text { GPCB (air) } \\
450(90 \%)\end{array}$} & \multirow{2}{*}{$\begin{array}{l}\text { GPCB (water) } \\
450(90 \%)\end{array}$} & \multirow{2}{*}{$\frac{\text { GPCC (air) }}{315(63 \%)}$} & \multirow{2}{*}{$\begin{array}{l}\text { GPCC (water) } \\
315(63 \%)\end{array}$} & \multirow{2}{*}{$\begin{array}{l}\text { OPCA (water) } \\
-\end{array}$} & \multirow{2}{*}{$\begin{array}{l}\text { OPCA (air) } \\
-\end{array}$} \\
\hline Binder (g) (\%) & GGFBS & & & & & & \\
\hline & F.S. & - & - & 135 (27\%) & 135 (27\%) & _- & - \\
\hline & $\mathrm{RB}$ & $50(10 \%)$ & $50(10 \%)$ & $50(10 \%)$ & $50(10 \%)$ & - & - \\
\hline & cement & _- & - & _- & - & $500(100 \%)$ & $500(100 \%)$ \\
\hline \multicolumn{2}{|l|}{ Sand(g) } & 1500 & 1500 & 1500 & 1500 & 1500 & 1500 \\
\hline \multicolumn{2}{|l|}{ Activators (ml) } & 200 & 200 & 200 & 200 & - & - \\
\hline \multicolumn{2}{|l|}{ Water (mm) } & - & - & - & - & 200 & 200 \\
\hline \multicolumn{2}{|c|}{ Curing method } & Ambient air & In water & Ambient air & In water & Ambient air & In water \\
\hline \multicolumn{2}{|l|}{$\mathrm{NaOH}: \mathrm{Na}_{2} \mathrm{SiO}_{3}$} & 1:03 & $1: 03$ & $1: 03$ & $1: 03$ & - & - \\
\hline \multicolumn{2}{|c|}{ Molarity of $\mathrm{NaOH}$} & 12 & 12 & 10 & 10 & _- & - \\
\hline
\end{tabular}

pipes were collected and prepared for the infrared scanning analysis (FTIR) test. These samples were stored until the time of testing. The samples are ground and molded with a small amount of potassium bromide and then pressed to a disk of $13 \mathrm{~mm}$ in diameter at a pressure of $8 \mathrm{t} / \mathrm{cm}^{2}$ for FTIR analysis. The wave number ranged from 400 to $4000 \mathrm{~cm}^{-1}$.

Reinforcing steel corrosion behavior has been measured by extracting steel bars from pipes after accelerated corrosion setup and loading frame test and putting in tap water. Linear polarization techniques have been used to determine the variation in the corrosion process following ASTM C 876 also Tafel equation. The voltalab test aimed to measure the effect of different parameters that concrete pipes have been exposed to on the embedded steel bars. The polarization experiments have been carried out at a scan rate of $20 \mathrm{mV} / \mathrm{S}$. The Voltalab measurements were performed under temperature $21^{\circ} \mathrm{C}$ and humidity $45 \%$.

\section{Results and discussion}

\section{Compressive strength}

\section{Compressive strength of mortar mixes GPCB, GPCC, and OPCA}

Sets of mortar mixes have been tested to reach optimized mixes for main concrete mixes. Figure 9 represents the variation in compressive strength at different mortar mixes. The increase in strength of geopolymer concrete mixes produced of $90 \%$ GBFS

Table 5 Mix id and mix batch composition of concrete mixes

\begin{tabular}{lllll}
\hline Concrete indent & & GPCB & GPCC & OPCA \\
\hline Binder composition $(\mathrm{kg})(\%)$ & Slag & $3.15(90 \%)$ & $2.2(63 \%)$ & - \\
& Fly ash & - & $0.945(27 \%)$ & - \\
& Red mud & $0.350(10 \%)$ & $0.35(10 \%)$ & - \\
& cement & - & - & $3.5(100 \%)$ \\
Binder content $\left(\mathrm{kg} / \mathrm{m}^{3}\right)$ & & 500 & 500 \\
Basalt $\left(\mathrm{kg} / \mathrm{m}^{3}\right)$ & 1165 & 1165 & 1044 \\
Sand $\left(\mathrm{kg} / \mathrm{m}^{3}\right)$ & 570 & 570 & 511 \\
Activator $\left(\mathrm{kg} / \mathrm{m}^{3}\right)(\mathrm{w} / \mathrm{b})$ & $262(0.524)$ & $290(0.58)$ & - \\
Water $\left(\mathrm{kg} / \mathrm{m}^{3}\right)(\mathrm{W} / \mathrm{c})$ & - & - & $250(0.5)$ \\
Molarity of $\mathrm{NaOH}$ & 12 & 10 & - \\
$\mathrm{NaOH}: \mathrm{Na} \mathrm{SiO}_{3}$ & & 113 & 113 & - \\
\hline
\end{tabular}


Table 6 Main properties of the tested pipes

\begin{tabular}{|c|c|c|c|c|c|}
\hline \multirow{2}{*}{$\begin{array}{l}\text { Pipe } \\
\text { no. }\end{array}$} & \multirow[t]{2}{*}{ Pipes indent. } & \multirow{2}{*}{$\begin{array}{l}\text { Concrete } \\
\text { mix type }\end{array}$} & \multirow{2}{*}{$\begin{array}{l}\text { Wall } \\
\text { thickness, } \\
\mathrm{h}(\mathrm{mm})\end{array}$} & \multicolumn{2}{|l|}{ Solution aggression } \\
\hline & & & & ACS period (month) & Environment type \\
\hline 1 & OPCA100(TW) & OPCA & 100 & 3 & $\begin{array}{l}\text { TW } \\
0\end{array}$ \\
\hline 2 & OPCA100(MS-Cl) & & 100 & 3 & $\begin{array}{l}\text { MS-CL } \\
5\end{array}$ \\
\hline 3 & GPCB100(TW) & GPCB & 100 & 3 & $\begin{array}{l}\text { T.W. } \\
0\end{array}$ \\
\hline 4 & GPCB100(MS-Cl) & & 100 & 3 & $\begin{array}{l}\text { MS-CL } \\
5\end{array}$ \\
\hline 5 & GPCC100(TW) & GPCC & 100 & 3 & $\begin{array}{l}\text { T.W. } \\
0\end{array}$ \\
\hline 6 & GPCC100(MS-Cl) & & 100 & 3 & $\begin{array}{l}\text { MS-CL } \\
5\end{array}$ \\
\hline
\end{tabular}

and $10 \% \mathrm{RB}$ (GPCB) in case of water curing is $9 \%$ compared to that in case of air curing at 28 days. The increase in strength of geopolymer concrete mixes produced of $63 \%$ GBFS, $27 \% \mathrm{FA}$, and $10 \% \mathrm{RB}$ (GPCC) in case of water curing is $20 \%$ compared to that in the case of air curing at 28 days. The increase in strength of OPC concrete mixes (OPCA) in the case of water curing is $86 \%$ compared to that in the case of air curing at 28 days. Figure 9 shows increases in compressive strength in water curing case more than air curing case in all samples in both time intervals 7 days and 28 days. On the contrary, Yewale et al. [26] stated that the mechanical strength result of geopolymer concrete cured at ambient temperature is promising compared to water curing.

\section{Compressive strength of concrete mixes GPCB, GPCC, and OPCA}

Figure 10 shows the compressive strength of tested samples for different concrete mix periods: GPCB, GPCC, and OPCA. The comparison of compressive strength is also shown of tested concrete samples for various curing media in Fig. 10, indicating similar compressive strength results of tested mortar samples in this study. The compressive strength for all the mixes in the water curing case is higher than in the ambient curing case.

The compressive strength of OPCA samples immersed in MS-CL decreased compared to OPCA samples immersed in TW. The reduction in strength of OPCA concrete samples immersed in MS-CL is $35 \%$ compared to the samples immersed in TW at the flexural test day. The loss of compressive strength of OPCA concrete samples in aggressive media is attributed to the reaction between sulfate ions with hydrated calcium aluminate and calcium hydroxide forming ettringite and gypsum. These products occupy a greater volume than the compounds they replace, leading to the expansion of hardened concrete and loss of its strength. Then, sulfate carbonation decomposes

Table 7 Geometric and mechanical properties of the used high deformed and mild steel bars complying with ESS 262/2009

\begin{tabular}{lllllll}
\hline $\begin{array}{l}\text { Type } \\
\text { of } \\
\text { steel }\end{array}$ & $\begin{array}{l}\text { Nominal bar } \\
\text { diameter }(\mathbf{m m})\end{array}$ & $\begin{array}{l}\text { Actual bar } \\
\text { diameter } \\
(\mathbf{m m})\end{array}$ & $\begin{array}{l}\text { Actual cross- } \\
\text { sectional area } \\
\left(\mathbf{m m}^{\mathbf{2}}\right)\end{array}$ & $\begin{array}{l}\text { Yield stress } \\
\left(\mathbf{N} / \mathbf{m m}^{\mathbf{2}}\right)\end{array}$ & $\begin{array}{l}\text { Ultimate } \\
\text { strength }(\mathbf{N} / \\
\left.\mathbf{m m}^{\mathbf{2}}\right)\end{array}$ & $\begin{array}{l}\text { Elongation } \\
(\%)\end{array}$ \\
\hline $\begin{array}{l}\text { Mild } \\
\text { steel }\end{array}$ & 8 & 7.7 & 47 & 303.3 & 460.2 & 25 \\
\hline
\end{tabular}




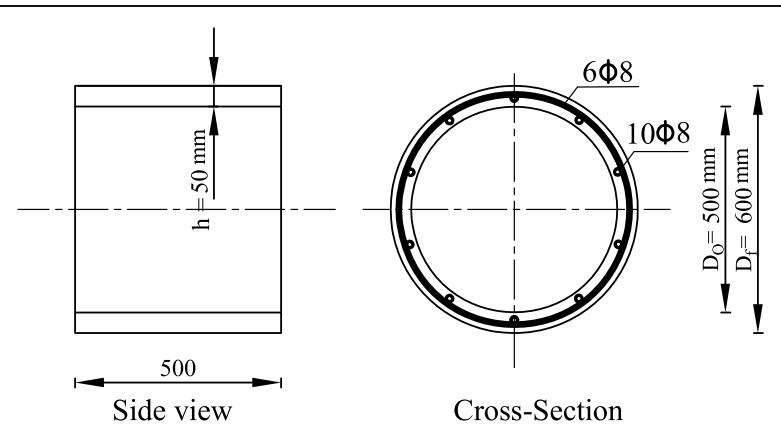

(a) Pipes with $50 \mathrm{~mm}$ thickness

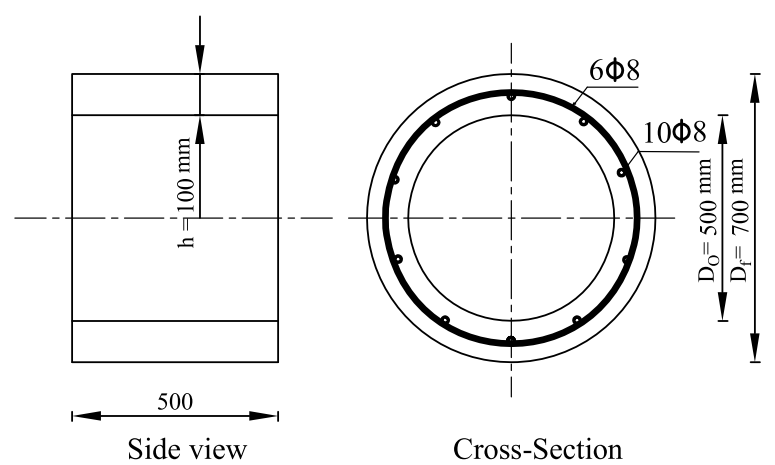

(b) Pipes with $100 \mathrm{~mm}$ thickness

Fig. 2 Concrete dimensions and details of reinforcement of concrete pipes a pipes with thickness $50 \mathrm{~mm} \mathbf{b}$ with thickness $100 \mathrm{~mm}$ (all dimensions are in $\mathrm{mm}$ )

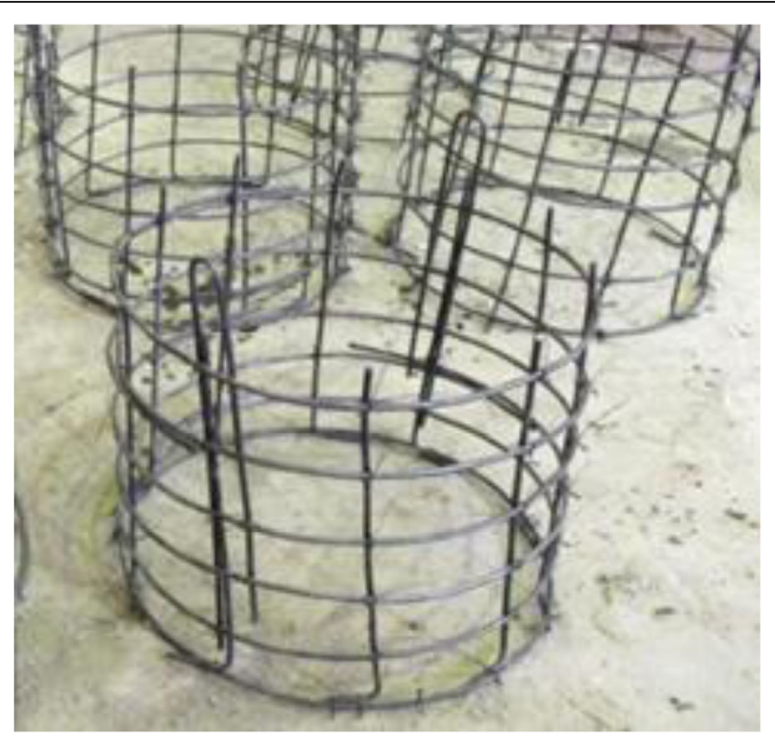

Fig. 3 The typical reinforcement of the pipes 


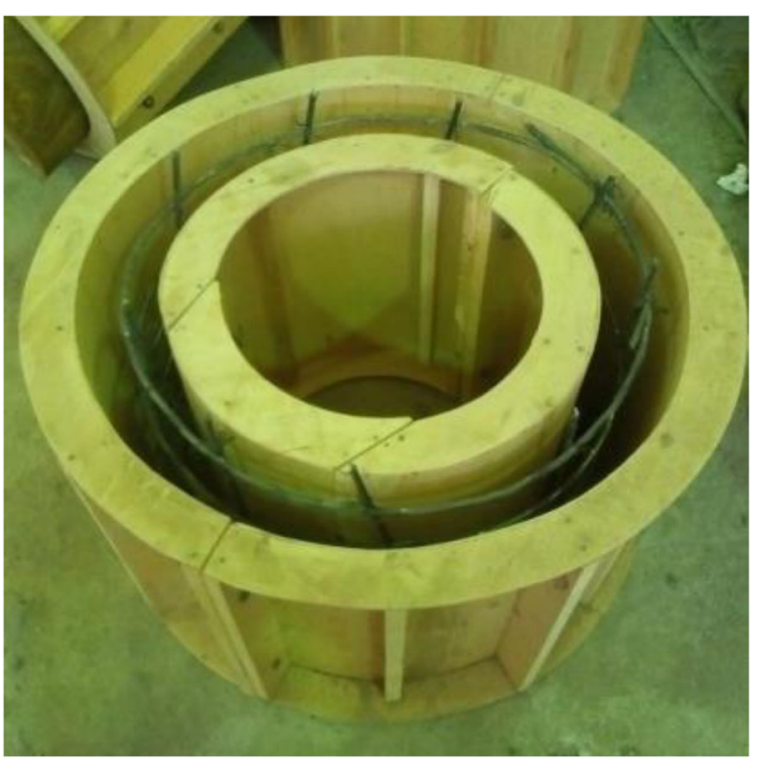

Fig. 4 A wooden mold of pipes

hydrated calcium silicates gel (CSH) to hydrated magnesium silicate gel (MSH), which has no binding properties [27]. Also, the presence of chlorides in aggressive media cause in decomposing of gypsum and ettringite in hardened concrete and leaching out of the concrete. Therefore, the porosity of the concrete increases, and its strength decrease [27].

By comparing the compressive strength of GPCB and GPCC concrete samples in all cases, it is evident that GPCB samples have higher compressive strength than GPCC samples in all cases, which agrees with previous literature [23, 28]. This is attributed to the increase in GGBFS content, generating more geopolymerization products (CSH/ $\mathrm{NASH}$ ), which increases the compressive strength of concrete. The reduction in strength of GPCB samples immersed in aggressive media is only $11 \%$ compared to

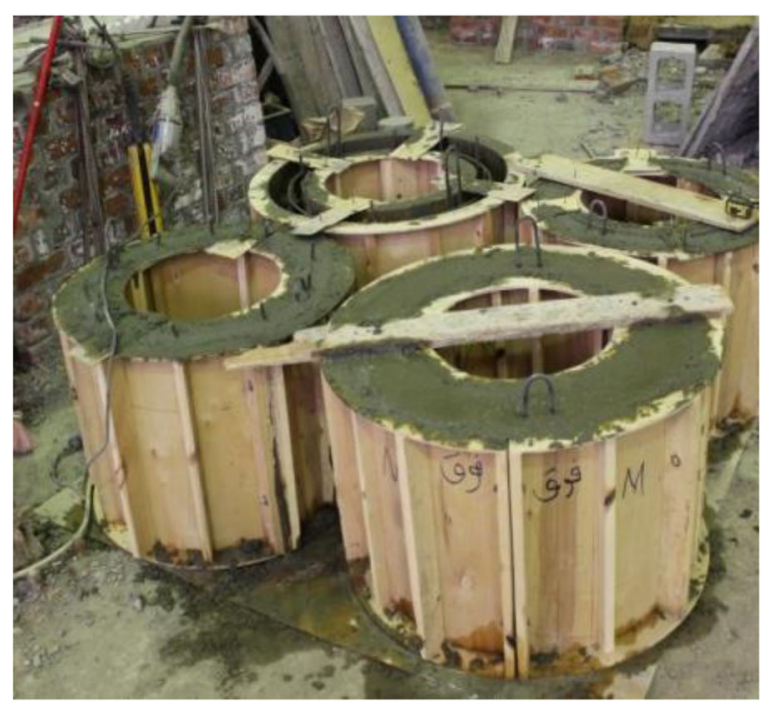

Fig. 5 The concrete casting of pipes 


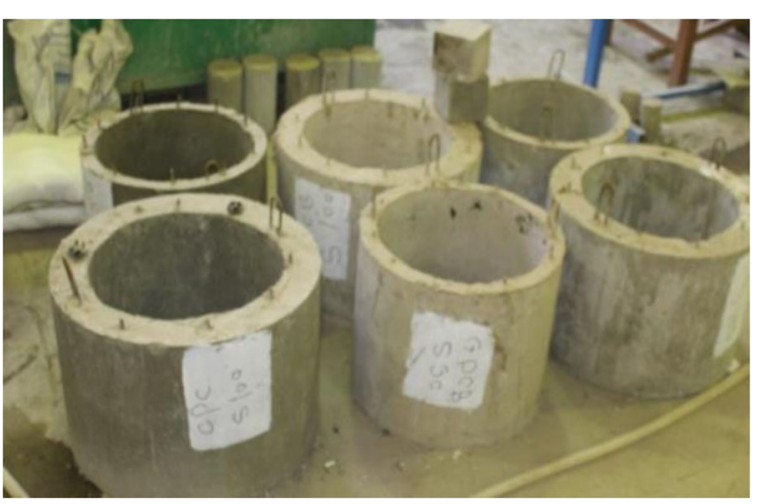

Fig. 6 Curing of pipes in ambient air

samples immersed in TW at the flexural test day. This may be attributed to forming a more stable CSH gel matrix with NASH-type gel and the reduction in $\mathrm{AL}[25,28]$. In case GPCC samples immersed in aggressive media perform well and show increasing strength by $5 \%$ compared to sample engaged in TW. As a result of fly ash in GPCC samples, there is a gain in strength in aggressive media. This improvement may be attributed to magnesium diffusion, which occurred along with the migration of alkali ions [29].

\section{Flexural test of pipes}

Six concrete pipes have been tested by the loading frame test [1]. The experimental investigation has been based on failure load, load-mid-span (vertical) deflection, and load-mid-span (horizontal) deflection. The details of the tested pipes are mentioned in Table 6. In general, GPCB RC pipes perform better than OPCA and GPCC RC pipes under aggressive environment [1]. Figure 11 shows the load capacity of OPCA100, GPCB100, and GPCC100 samples exposed to accelerated corrosion set up for three months with different aggressive media [1]. It can be seen the different effects of aggressive media between different pipes types OPCA100 (MS-CL), GPCB100 (MS-CL), and GPCC100 (MS-CL) in Fig. 12. From Fig. 12, it can be concluded that the effect of aggressive media on GPCB pipes is the lowest on OPC and GPCC pipes [1].

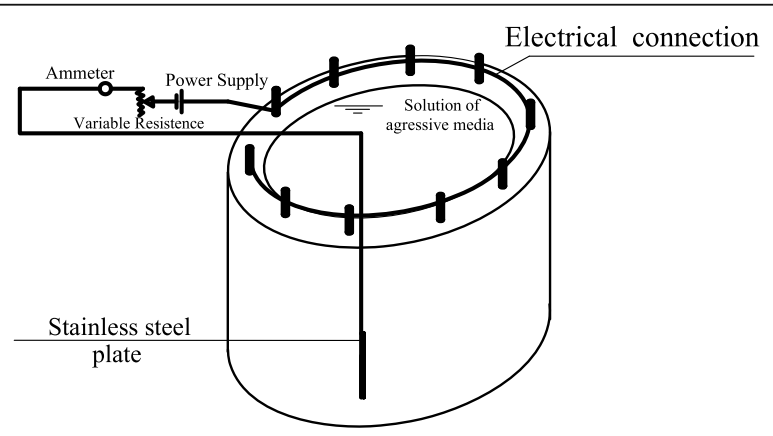

Fig. 7 Schematic representation of the accelerated corrosion setup 


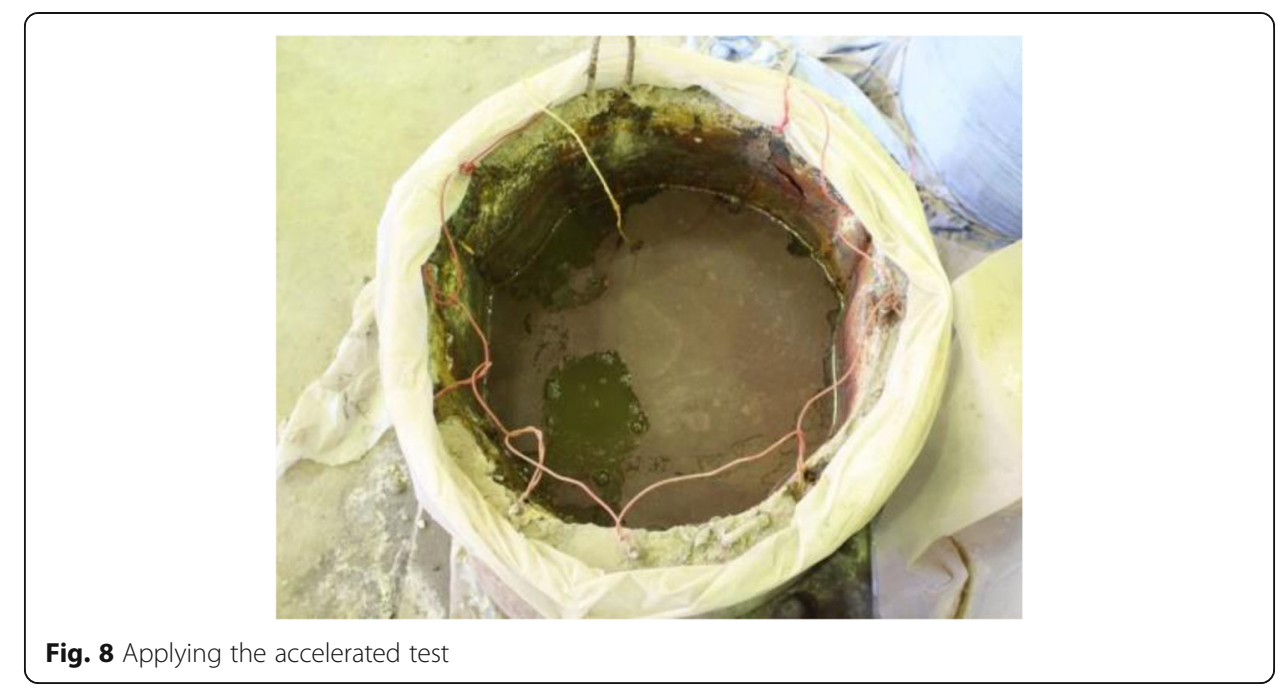

\section{Corrosion behavior of steel from concrete pipes after flexural test}

Linear polarization techniques have been used to determine the variation in the corrosion process also the Tafel equation. Table 8 shows the corrosion potential at zero current potential $E(i=0)(\mathrm{mV})$, polarization resistance $R p\left(\mathrm{k} \Omega \cdot \mathrm{cm}^{2}\right)$, and corrosion rate $(\mu \mathrm{m} / Y)$ for all samples. Geopolymer concrete has high corrosion resistance compared to the OPCA samples; this can be attributed to the higher density (higher compressive strength) and higher P.H. value of pore solution in geopolymer concrete than the OPCA samples. Also, geopolymer concrete possesses higher resistance to be decomposed by magnesium sulfate attack. As a result of existing slag in geopolymer concrete, it inhibits chloride ions from reaching the reinforcement [30, 31].

\section{Microstructure of concrete mixes of pipes (infrared analysis (IR))}

Figures 13, 14, and 15 show the FTIR spectra of OPCA100, GPCB100, and GPCC100 samples exposed to accelerated corrosion setup periods with different aggressive media. In the case of OPCA samples, by comparison, the spectra of OPCA samples immersed in tap water within aggressive media show a loss of Si-O bound 443 and $960 \mathrm{~cm}^{-1}$ in $\mathrm{CSH}$ gel. This can be attributed to the formation of hydrated magnesium silicate, which has no bonding ability from sulfate attack on OPC concrete in addition to leaching

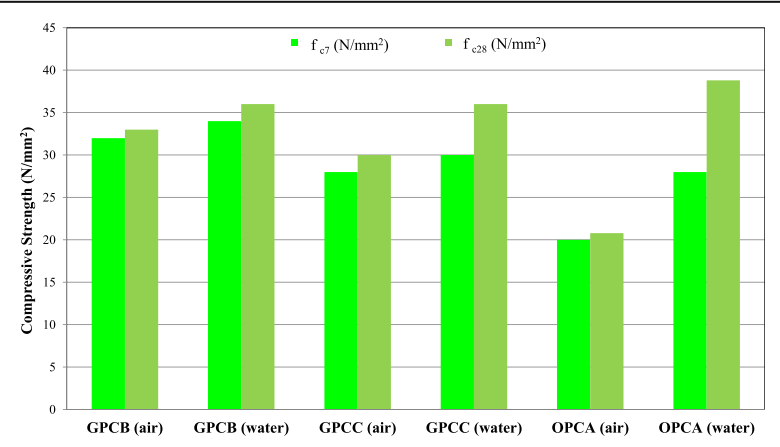

Fig. 9 The variation in compressive strength at different mortar mixes 


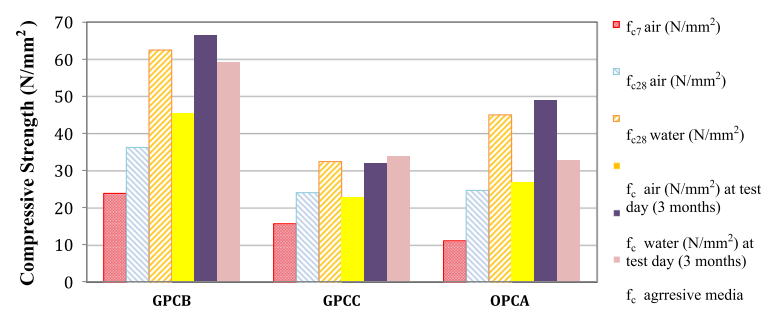

Fig. 10 The variation in compressive strength at different concrete mixes

effect of chloride attack on concrete [27]. The stretching vibration of the carbonated band at $1400 \mathrm{~cm}^{-1}$ shows loss of calcite in the OPC concrete due to the higher porosity of concrete. From stretching vibration of water-bound at $3390 \mathrm{~cm}^{-1}$ and bending vibration of bound water $(\mathrm{HOH})$ at $1620 \mathrm{~cm}^{-1}$, it is evident that there is a loss of crystalline water in OPC concrete leading to a loss in strength and higher permeability [27].

In the case of GPCB and GPCC samples, by comparison, the spectra of GPCB and GPCC samples immersed in tap water within aggressive media, it is evident that the gain of $\mathrm{Si}-\mathrm{O}$ band is noticeable at 450 and $970 \mathrm{~cm}^{-1}$ in geopolymer matrix. This can be attributed to using the high ratio of $\mathrm{Na}_{2} \mathrm{Sio}_{3}$ in the alkali activator solution [32]. From stretching vibration of water-bound at $3400 \mathrm{~cm}^{-1}$ and bending vibration of bound water $(\mathrm{HOH})$ at $1625 \mathrm{~cm}^{-1}$, it was evident that the denser form of crystalline water in the geopolymer matrix gains strength and lower permeability [33].

\section{Conclusions}

In this paper, an experimental program of two different groups was investigated; these two groups are mortar and concrete mixes: two geopolymer mortar mixes containing sodium-based activator combinations in addition to one OPC mix and two geopolymer concrete mixes containing sodium-based activators combinations in addition to one OPC mix under different mix compositions. This study aims to present the significance of using geopolymer mixes in RC pipes under an aggressive environment. In many studies, the effect of an aggressive environment on geopolymer mixes has been studied. In this study, the effect of aggressive environment on RC pipes produced of different geopolymer mixes under accelerated corrosion setup was studied compared with RC pipes produced of OPC mix. Based on the obtained results, the following conclusion can be drawn:

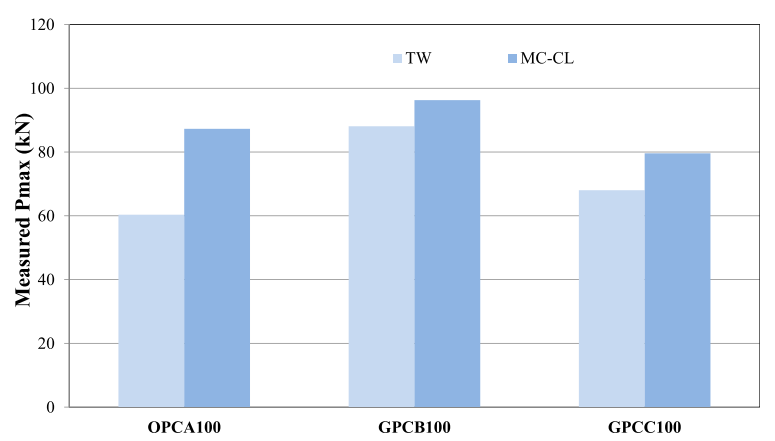

Fig. 11 Loading capacity of OPCA100, GPCB100, and GPCC100 samples under ACS with different aggressive media [1] 


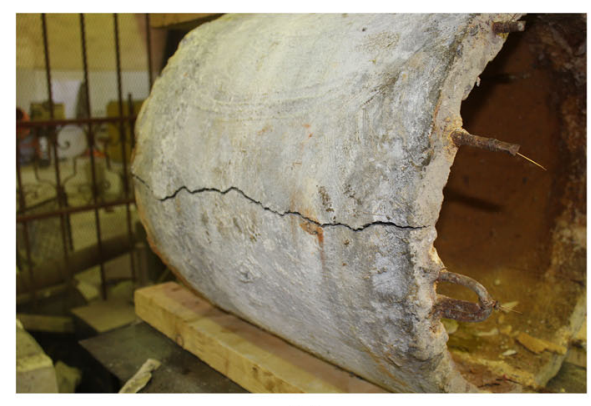

(a)

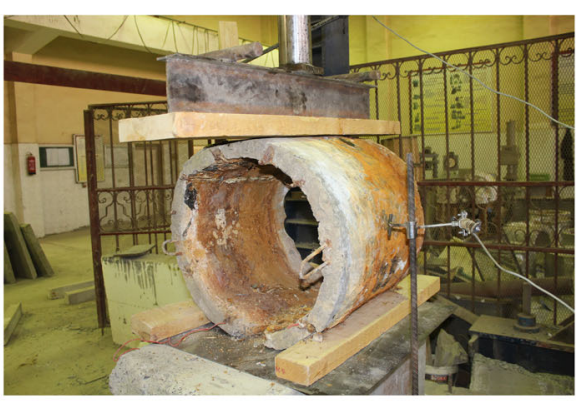

(b)

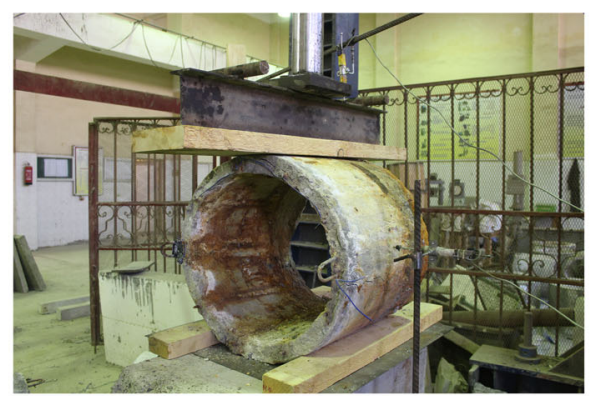

(c)

Fig. 12 Failure of pipe a OPCA100(MS-CL), b GPCB100(MS-CL), and c GPCC100(MS-CL) [1]

1. The compressive strength of mortar mixes in the case of water curing has a higher value than air curing in all samples.

2. All the tested geopolymer concrete mixes produced of $90 \%$ GBFS and $10 \%$ RB possessed the highest compressive strength compared to geopolymer concrete mixes based on 63\% GBFS, 27\% FA, and 10\% RB for all cases.

3. Geopolymer concrete mixes based on 63\% GBFS, 27\% FA, and 10\% RB increase the concrete compressive strength in the magnesium sulfate and chloride environment by $5 \%$ compared to tap water.

4. Geopolymer structure of geopolymer samples has a more stable form than ordinary Portland cement concrete structure.

5. In general, geopolymer concrete pipes inhibit an increase in the corrosion rate over time despite using accelerated corrosion setup and aggressive media compared with ordinary Portland cement concrete pipes. This can be attributed to the essential features of geopolymer concrete: the lower presence of $\mathrm{CaOH}$, lower permeability of geopolymer mixes, high density of geopolymer samples, high compressive strength, and high $\mathrm{PH}$ value and the presence of slag materials.

Table 8 The variation in electrochemical results of the reinforcing steel after exposure to accelerated corrosion setup

\begin{tabular}{lllll}
\hline Pipes indent. & $\boldsymbol{E}(\boldsymbol{i}=\mathbf{0})(\mathbf{m v})$ & $\boldsymbol{i}$ corrosion $\left(\boldsymbol{\mu A} / \mathbf{c m}^{2}\right)$ & $\boldsymbol{R p}\left(\mathbf{k} \boldsymbol{\Omega} . \mathbf{c m}^{2}\right)$ & Corrosion $(\boldsymbol{\mu m} / \boldsymbol{\gamma})$ \\
\hline OPCA100 (MS-CL) & -530.8 & 8.021 & 3.29 & 93.82 \\
GPCB100 (MS-CL) & -744.6 & $17.19 \times 10^{-3}$ & 22.8 & $200.9 \times 10^{-3}$ \\
GPCC100 (MS-CL) & -766.7 & $1.6973 \times 10^{-3}$ & $1.28 \times 10^{3}$ & $19.85 \times 10^{-3}$ \\
\hline
\end{tabular}




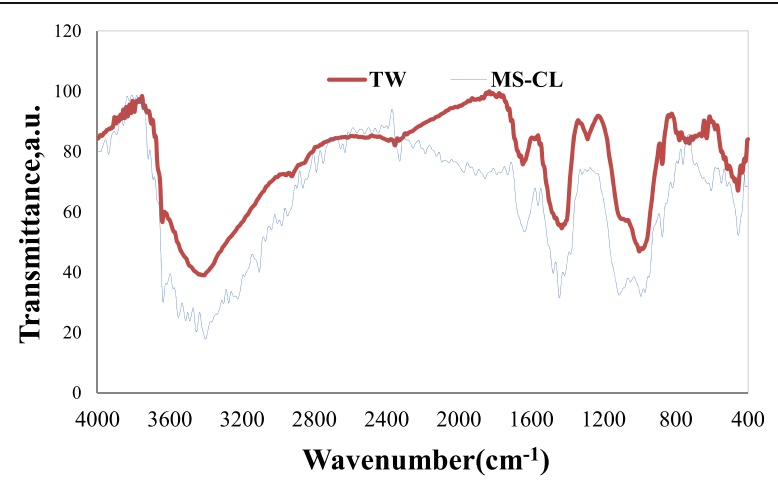

Fig. 13 I.R. spectra of OPCA100 samples under ACS with different aggressive media

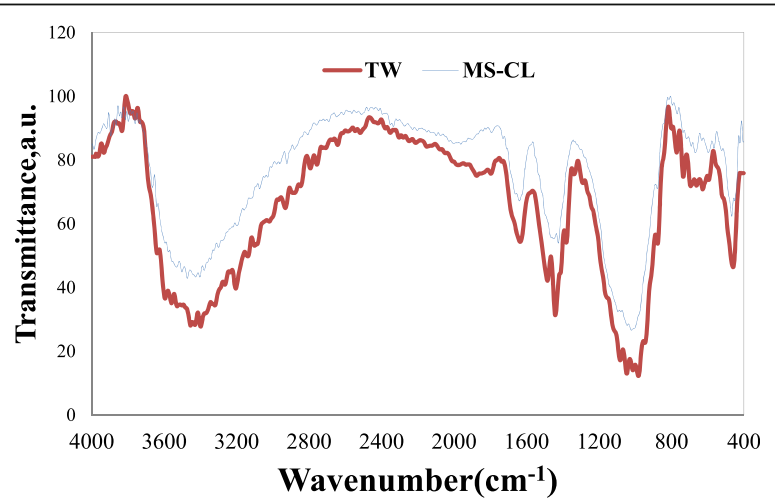

Fig. 14 I.R. spectra of GPCB100 samples under ACS with different aggressive media

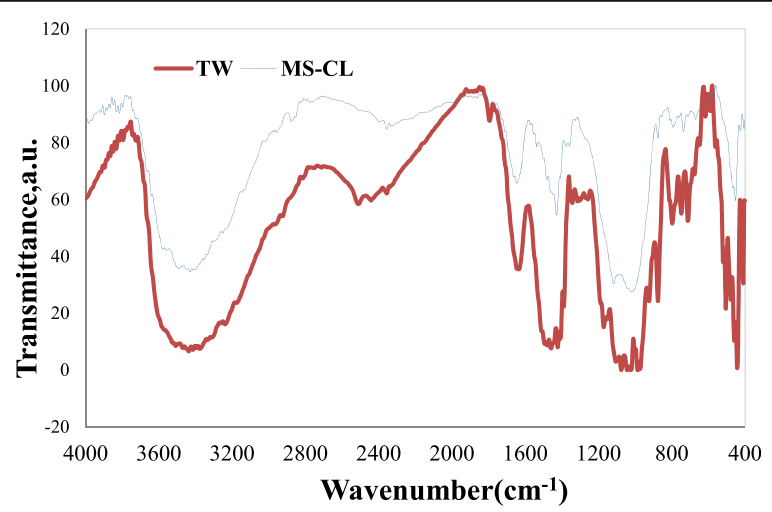

Fig. 15 I.R. spectra of GPCC100 samples under ACS with different aggressive media 
6. This investigation will help to improve structural performance and corrosion resistance of RC pipes under aggressive media by using geopolymer mixes in RC pipes.

\section{Future works}

1. Using other mixes of geopolymer binder and alkaline activator materials

2. Producing concrete pipes by centrifugal casting as a standard casting method in factories alternative to regular casting

3. Applying these geopolymer concrete mixes in pipes factories by standard dimensions

4. Reforming damaged buildings from corrosion or fire attack by using geopolymer mortar as coating material

\section{Abbreviations}

RC: Reinforced concrete; OPC: Ordinary Portland cement; GBFS: Granulated blast furnace slag; FA: Fly ash; RB: Pulverized red brick; TW: Tap water; MS-CL: Solution of 10\% magnesium sulfates $+5 \%$ chloride; FTIR: Fourier transform infrared; XRF: X-ray fluorescence; $\mathrm{NaOH}$ : Sodium hydroxide; $\mathrm{Na}_{2} \mathrm{SiO}_{3}$ : Sodium silicate; CEM I: Ordinary Portland cement; ACS: Accelerated corrosion setup; DC: Direct current; CSH: Calcium silicate gel; MSH: Hydrated magnesium silicate gel; $\mathrm{E}(\mathrm{i}=0)$ : Corrosion potential at zero current potential; Rp: Polarization resistance; $\mathrm{HOH}$ : $\mathrm{Bound}$ water

\section{Acknowledgements}

Not applicable

\section{Authors' contributions}

MG supervised the perpetration of samples and controlled the laboratory machines with aid from AE, WS, and HE. LO wrote the manuscript and analyzed the results. All authors read and approved the final manuscript.

\section{Funding}

No funding source is available.

\section{Availability of data and materials}

The datasets used and analyzed during the current study are available from the corresponding author on reasonable request.

\section{Declarations}

Competing interests

The authors declare that they have no competing interests.

\section{Author details}

${ }^{1}$ Faculty of Engineering, Fayoum University, Faiyum, Egypt. ${ }^{2}$ Civil Engineering Department, Faculty of Engineering,

Fayoum University, Faiyum, Egypt. ${ }^{3}$ Housing and Building National Research Center, Cairo, Egypt.

Received: 18 September 2021 Accepted: 6 December 2021

Published online: 08 January 2022

\section{References}

1. Omar LM (2019) Durability of RC pipes made of geopolymer concrete materials subjected to aggressive corrosive media. JOSR J Mech Civil Eng (IOSR-JMCE) 16(4) Ser. I (2019):47-58

2. Gourley JT, Johnson GB (2019) The corrosion resistance of geopolymer concrete sewer pipe. Con in Aust 43(1)

3. Maras MM, Kose M (2021) M (2020) Structural behavior of masonry panels strengthened using geopolymer composites in compression tests, Iran J of Sci and Tech. Trans Civil Eng 45(2):767-777. https://doi.org/10.1007/s40996-020-00433-6

4. Maras MM (2021) Mechanical and fracture behavior of geopolymer composites reinforced with fibers by using Nano$\mathrm{TiO}_{2}$.J of the Brazi Soc of Mech Sci and Eng 43(2021):412. https://doi.org/10.1007/s40430-021-03135-w

5. Maras M (2021) M (2021) Characterization of Performable geopolymer mortars for use as repair material. Struc Con 22(5): 3173-3188. https://doi.org/10.1002/suco.202100355

6. Mohamed N (2015) Experimental and numerical study on full-scale precast steel fibre-reinforced concrete pipes, Ph.D. Thesis. Faculty of Engineering, The University of Western Ontario, London, Ontario, Canada

7. Yang Y, Zhang R Q.U. B (2015) Reinforced concrete sewer pipes used for jacking construction of experimental research and finite element analysis. Paper Presented Int Conf Mater Sci Appl

8. Peyvandi A, Soroushian P, Jahangirnejad S (2014) Structural design methodologies for concrete pipes with steel and synthetic fiber reinforcement. ACI Struct J (1). https://doi.org/10.14359/51686432 
9. Dhawan S, Bhalla S, Bhattacharjee B (2014) Reinforcement corrosion in concrete structures and service life predictions a review. Paper presented at the 9th International Symposium on Advanced Science and Technology in Experimental Mechanics, Delhi, India

10. Cahyadi JH, Uomoto T (1993) Influence of relative environmental humidity on concrete carbonation (mathematical modeling). Durab Build Mater Components:1142-1151

11. Chung L, Najm H, Balaguru P (2008) Flexural behavior of concrete slabs with corroded bars. Cement Concrete Compos 30(3):184-193. https://doi.org/10.1016/j.cemconcomp.2007.08.005

12. Bhargava K, Mori Y, Ghosh AK (2011) Time-dependent reliability of corrosion-affected R.C. beams_-Part 1: Estimation of time-dependent strengths and associated variability. Nucl Eng Desi 241(5):1371-1384. https://doi.org/10.1016/j. nucengdes.2011.01.005

13. Darmawan MS (2010) Pitting corrosion model for reinforced concrete structures in a chloride environment. Magaz Con Rese 62(2):91-101. https://doi.org/10.1680/macr.2008.62.2.91

14. El-Hefnawi AA (2000) A new statistical approach for predicting the residual capacity of reinforced concrete beams having corroded main steel, Ph.D. Thesis. Faculty of Engineering, Cairo University, Egypt

15. Khafaga MA (2002) Experimental and theoretical study for estimating the structural behavior and the residual capacity of reinforced concrete short columns with corroded rebars, Ph.D. Thesis. Faculty of Engineering, Cairo University, Egypt

16. Tuutti K (1982) Corrosion of steel in concrete. Swedish Cement and Concrete Research Institute. Stockholm, Sweden

17. Omer LM (2014) Time-dependent flexural capacity of R.C. slabs with corroded bars. M.Sc. Thesis. Faculty of Engineering, Fayoum University, Egypt

18. Selvakumar A, Matthews JC, Condit W (2014) Demonstration of an innovative large-diameter sewer rehabilitation technology in Houston, Texas. Society for Trenchless Technology, North American

19. Ernesto J Guides Ph.D(2016) Experimental investigation of the compressive and tensile strengths of geopolymer mortar: the effect of sand/fly ash (S/FA) ratio. Const Build Mat 127(2016):484-493. https://doi.org/10.1016/j.conbuildmat.2016.10. 030

20. Madheswaran CK, Ambily PS, Dattatreya JK, Ramesh G (2015) Experimental studies on the behavior of reinforced geopolymer concrete beams subjected to monotonic static loading. J Inst Eng, India 96(2):139-149. https://doi.org/10.1 007/s40030-015-0115-1

21. Neupane K (2016) Fly ash and GGBFS based powder-activated geopolymer binders: a viable, sustainable alternative of portland cement in the concrete industry. Mech Mater 103:110-122. https://doi.org/10.1016/j.mechmat.2016.09.012

22. Karakoç MB, Türkmen I, Maraş MM, Kantarci F (2016) Sulfate resistance of ferrochrome slag based geopolymer concrete. Ceram Int. 42(1):1254-1260. https://doi.org/10.1016/j.ceramint.2015.09.058

23. Gopalakrishnan R, Chinnaraju K (2019) Durability of ambient cured alumina silicate concrete based on slag/fly ash blends against sulfate environment. Const Build Mat 204:70-83. https://doi.org/10.1016/j.conbuildmat.2019.01.153

24. Kannapiran K, Sujatha T. Nagan S (2013) Resistance of reinforced geopolymer concrete beams to acid and chloride migration, Asian J Civil Eng 14, 2, 225-238

25. Shi C, Krivenko P, Roy D (2003) Alkali-activated cements and concretes, 1st edn. Press, CRC. https://doi.org/10.1201/ 9781482266900

26. Yewale W, Shirsath MN, Hake SL (2016) Evaluation of efficient type of curing for geopolymer concrete. Int J New Tech Sci Eng 3(8) ISSN 2349-0780. https://journalnx.com/journal-article/20150631

27. Neville AM, Brooks JJ (2010) Concrete technology, 2nd edn. Education, Pearson

28. Rajini B, Narasimha Rao AV, Sashidhar C (2020) Micro-level studies of fly ash and GGBS -based geopolymer concrete using Fourier transform infra-red. Mater Today Proc 46:586-589. https://doi.org/10.1016/j.matpr.2020.11.291

29. Bakharev T (2005) Durability of geopolymer materials in sodium and magnesium sulfate solutions. Cem Con Res 35 : 1233-1246. https://doi.org/10.1016/j.cemconres.2004.09.002

30. Siti MS, Al Bakri AM, Kamarudin H, Ruzaidi CM, Binhussain M, Zaliha SZ (2013) Review on current geopolymer as a coating materiaL. Aust J Bas App Sci 7(5):246-257

31. McCaffrey R (2002) Climate change and the cement industry. Glob Cement Lime Maga, Environmental Special Issue, pp $15-19$

32. Krivenko PV (1986) Synthesis of cementitious materials in a system R2O-Al2O3-SiO2-H2O with required properties, D. Sc. (Eng.) Thesis. Kiev Civil Engineering Institute, Kiev, Ukraine

33. Donatello S, Palomo A, Fernandes-Jimenez A (2013) Durability of very high volume fly ash cement pastes and mortars in aggressive solutions. Cem Con Comp 38:12-20. https://doi.org/10.1016/j.cemconcomp.2013.03.001

\section{Publisher's Note}

Springer Nature remains neutral with regard to jurisdictional claims in published maps and institutional affiliations. 